\title{
Assessing a single SNP located at TERT/CLPTM1L multi-cancer risk region as a genetic modifier for risk of pancreatic cancer and melanoma in Dutch CDKN2A mutation carriers
}

\author{
E. Christodoulou ${ }^{1}$ (1) $\cdot$ M. Visser ${ }^{1} \cdot$ T. P. Potjer ${ }^{2} \cdot$ N. van der Stoep ${ }^{2} \cdot$ M. Rodríguez-Girondo ${ }^{3} \cdot$ R. van Doorn ${ }^{1} \cdot$ N. Gruis $^{1}$
}

Published online: 15 June 2019

(c) The Author(s) 2019

\begin{abstract}
Carriers of pathogenic variants in $C D K N 2 A$ have a $70 \%$ life-time risk of developing melanoma and $15-20 \%$ risk of developing pancreatic cancer (PC). In the Netherlands, a 19-bp deletion in exon 2 of CDKN2A (p16-Leiden mutation) accounts for most hereditary melanoma cases. Clinical experience suggests variability in occurrence of melanoma and PC in p16-Leiden families. Thereby, the risk of developing cancer could be modified by both environmental and genetic contributors, suggesting that identification of genetic modifiers could improve patients' surveillance. In a recent genome-wide association study (GWAS), rs36115365-C was found to significantly modify risk of PC and melanoma in the European population. This SNP is located on chr5p15.33 and has allele-specific regulatory activities on TERT expression. Herein, we investigated the modifying capacities of rs36115365-C on PC and melanoma in a cohort of 283 p16-Leiden carriers including 29 diagnosed with PC, 171 diagnosed with melanoma, 21 diagnosed with both PC and melanoma and 62 with neither PC nor melanoma. In contrast to previously reported findings, we did not find a significant association of PC risk with risk variant presence as determined by Generalized Estimating Equations (GEE) modelling. Interestingly, carrier-ship of the risk variant had a significant protective effect for melanoma (OR -0.703 [95\% CI -1.201 to -0.205$], p=0.006$ ); however, the observed association was no longer significant after exclusion of probands to assess possible influence of ascertainment. Collectively, genetic modifiers for the prediction of PC and melanoma risk in p16-Leiden carriers remain to be determined.
\end{abstract}

Keywords $C D K N 2 A \cdot p 16$-Leiden $\cdot$ Pancreatic cancer $\cdot$ Melanoma $\cdot$ Genetic modifiers $\cdot$ SNP

\section{Introduction}

$C D K N 2 A$ is the major high-risk susceptibility gene identified thus far for familial melanoma [1]. In the Netherlands, the most common cause of familial melanoma is a $C D K N 2 A$ founder mutation which is a deletion of 19 bp in exon 2 (c.225_243del,

R. van Doorn and N. Gruis shared last authorship.

E. Christodoulou

e.christodoulou@lumc.nl

1 Department of Dermatology, Leiden University Medical Center (LUMC), Albinusdreef 2, 2333 ZA Leiden, The Netherlands

2 Department of Clinical Genetics, LUMC, Albinusdreef 2, 2333 ZA Leiden, The Netherlands

3 Section of Medical Statistics, Department of Biomedical Data Sciences, LUMC, Einthovenweg 20, 2333 ZC Leiden, The Netherlands
p.(A76Cfs*64); RefSeq NM_000077.4), also known as the p16-Leiden mutation resulting in inactivation of tumor-suppressive properties of p16(INK4a) [2]. Carriers have a lifetime risk of $70 \%$ to develop melanoma [3], and a life-time risk of 15-20\% to develop pancreatic cancer (PC) [4-6].

$\mathrm{PC}$ is a highly aggressive cancer subtype with very poor prognosis resulting in a 5-year survival rate of $<5 \%$ [7]. It is therefore one of the leading causes of cancer-related deaths worldwide [8], suggesting there is much to gain by early detection of PC at a stage when surgical removal is still curative [9]. Carriers of the p16-Leiden mutation are advised to undergo screening yearly for PC using MRI from the age of 45 [6].

Clinical studies of p16-Leiden mutated families, have shown variability in occurrence of melanoma and PC among families suggesting contribution of modifying factors to cancer risk [4]. For example, genetic risk factors such as $M C 1 R$, were found to modify risk of developing melanoma in p16-Leiden positive families significantly [10, 11]. Therefore, 
the variable occurrence of $\mathrm{PC}$ in those families might also be explained by modifying genetic risk factors other than the p16-Leiden mutation. Determination of those factors would allow for a better identification of patients at increased risk that might benefit from personalized clinical management.

In an attempt to identify genetic factors that modulate the risk of pancreatic cancer in p16-Leiden carriers, Potjer et al. analyzed seven SNPs associated with PC risk in the general population in this cohort of carriers and found no significant association [12]. Recently a risk variant, rs36115365-C, was identified to be significantly correlated with PC risk in the European population [13]. This SNP is located at a multi-cancer risk locus on chr5p15.33 and was found to have allele-specific regulatory activities on TERT expression, mutations of which have been associated with melanoma risk [14]. These data suggest that variation within rs36115365 (G,C) could contribute to cancer development. Indeed, carriers of the minor $\mathrm{C}$-allele are at increased risk of pancreatic cancer $(R R=1.2)$. Remarkably at the same time, carriers of this $\mathrm{C}$-allele are at diminished risk of developing melanoma [13]. Several risk variants have been reported to be associated with a small but important protective effect against melanoma in sporadic melanoma such as variants in GSTM1 and GSTT1 [15] and polymorphisms in the Vitamin $D$ receptor gene [16]. These findings collectively suggest that identification of genetic modifiers in p16-Leiden carriers could be used to estimate the risk of developing PC and melanoma more accurately. This study therefore, investigates and verifies the risk impact of the reported SNP variant, rs36115365-C in a Dutch p16-Leiden positive patient cohort.

\section{Methods}

\section{Cohort description}

The study population included only confirmed p16-Leiden carriers of which DNA samples were available from the
Laboratory for Diagnostic Genome Analysis (LDGA) of Leiden University Medical Center (LUMC). Subject-specific clinical information was collected between 1998 and the 1st of January, 2015. Cases of PC were individuals carrying the p16-Leiden mutation who were diagnosed with primary exocrine PC. Similarly, cases of melanoma were p16-Leiden carriers who were diagnosed with cutaneous (multiple) melanoma. Detailed medical record data on the study population has been reported previously [12]. Approval of this study was obtained from the ethics committee of Leiden University Medical Center (LUMC \#P14.148) [12].

In total, 419 p16-Leiden carriers were available for inclusion in the current study. The comparative analysis was formulated by filtering for carriers diagnosed with PC, carriers diagnosed with melanoma, and a group who did neither develop PC nor melanoma but were older than 55 years of age. Subsequently, a master cohort of 283 p16-Leiden carriers from a total of 121 pl6-Leiden families were included. These consisted of 29 carriers with PC (median age 47 years), 171 with melanoma (median age 60), 21 with both PC and melanoma (median age 60 ) and 62 with neither PC nor melanoma (median age 71) (Table 1).

\section{Genotyping and statistical analysis}

Genotyping analysis was carried out using the rhAmp-SNP Genotyping Assay (Integrated DNA Technologies (IDT), Leuven, Belgium). Bi-allelic discrimination was achieved by incorporation of two forward primers specifically targeting the allele of interest (rs36115365-C). The genotyping procedure was performed according to manufacturer's instructions. The reference allele was labelled with FAM reporter dye and the alternate allele with Yakima Yellow (YY) reporter dye which were both detected on CFX384 Touch Real-Time PCR Detection System (Bio-Rad, Veenendaal, The Netherlands) with excitation sources and emission filters for respective wavelengths. The minor allele frequency (MAF) was calculated based on Hardy-Weinberg law. For

Table 1 Master cohort characteristics of p16-Leiden carriers

\begin{tabular}{|c|c|c|c|c|}
\hline & \multicolumn{4}{|c|}{ pl6-Leiden carriers $(\mathrm{N}=283)$} \\
\hline & $\begin{array}{l}\text { Pancreatic cancer } \\
(\mathrm{N}=29)^{*}\end{array}$ & Melanoma $(\mathrm{N}=171)^{*}$ & $\begin{array}{l}\text { Pancreatic cancer and mela- } \\
\text { noma }(\mathrm{N}=21)\end{array}$ & $\begin{array}{l}\text { Non-melanoma, } \\
\text { non-pancreatic cancer } \\
(\mathrm{N}=62)^{*}\end{array}$ \\
\hline Median age (years) & $47(21-72)$ & $60(27-93)$ & $60(42-78)$ & $71(55-86)$ \\
\hline Gender (M:F) & $9: 20$ & $71: 100$ & $8: 13$ & $26: 36$ \\
\hline Multiple melanoma & - & $71 / 171(42 \%)$ & $6 / 21(29 \%)$ & - \\
\hline $\begin{array}{l}\text { Patients diagnosed with } \\
\text { other cancer }\end{array}$ & 3 & 33 & 6 & 24 \\
\hline
\end{tabular}

*p16-Leiden carriers who developed either pancreatic cancer or melanoma or neither of the two and were older than 55 years of age served as controls in comparative analysis, see Tables 2 and 3 
statistical analysis, a generalized linear model with logit link was used to assess the association between alternate-allele presence and risk for PC and melanoma development. The binary dependent variable was either PC or melanoma and SNP variant was the explanatory indicator variable. Regression coefficients and 95\% Confidence Intervals (CI) were calculated. $P$-values of $<0.05$ were considered statistically significant.

Due to nature of this family-based study, individuals are not independent, they are clustered. In order to account for this feature, a Generalized Estimating Equations (GEE) procedure was used to fit the model. The GEE procedure allows to deal with clustered data. Since the specific correlation structure of this data is difficult to estimate due to the small sample size, an independence working correlation structure was assumed. To avoid the impact of possible misspecification of the model in the confidence intervals and p-values, robust estimates of the standard errors were obtained using a sandwich estimator [17]. All statistical analyses were performed using IBM SPSS Statistics 23.

\section{Results}

The risk impact of rs36115365-C on PC was calculated by comparing a total of 50 p16-Leiden carriers who developed PC (median age 50) to 143 controls (median age 74) consisting of 62 carriers who did not develop PC and 81 carriers who developed melanoma but were older than 55 years of age (sub-cohort characteristics, Table 2). Similarly, the risk impact of rs36115365-C on melanoma was calculated by comparing a total of 192 p16-Leiden carriers who developed melanoma (median age 60) to 73 controls (median age 71), consisting of 62 carriers who did not develop melanoma and 11 carriers who developed PC but were older than 55 years of age (sub-cohort characteristics, Table 3). The latter group in both analyses was treated as a control since it consisted of p16-Leiden carriers older than 55 years of age with a subsequent reduced risk of developing melanoma or pancreatic carcinoma in the future.

MAF of the risk variant rs36115365-C for different comparison groups, Beta values and 95\% CI were calculated
(Table 4). No significant association was found for risk variant presence and PC risk (Table 4). Interestingly, a significant negative association was observed for risk variant carriers and melanoma development suggesting a protective effect of rs36115365-C for melanoma in p16-Leiden carriers $(\mathrm{OR}-0.703,95 \% \mathrm{CI}(-1.201,-0.205), \mathrm{p}$-value $=0.006)$ (Table 4). To assess possible influence of ascertainment in the sample cohort, the association with melanoma was further explored by excluding probands. This resulted in a decreased cohort size of 69 families consisting of 158 p16-Leiden carriers, 85 of whom had developed melanoma. The statistical significant association did not remain in that case for risk variant carriers (GEE model $-0.453,95 \%$ CI $(-1.051,0.145), \mathrm{p}$-value $=0.138)$.

\section{Discussion}

Identification of genetic modifiers for PC and melanoma risk in p16-Leiden carriers could possibly explain the variability of cancer occurrence within p16-Leiden positive families and ultimately favor individualized surveillance and clinical management of those patients $[4,12]$. Herein, we sought to estimate the risk of developing PC and melanoma more accurately in carriers of the pathogenic variant p16-Leiden. This was tested by determining whether a previously published associated risk variant for PC and melanoma,

Table 3 Sub-cohort characteristics of p16-Leiden carriers with/without melanoma

\begin{tabular}{lll}
\hline & $\begin{array}{l}\text { Melanoma } \\
\text { cases }(\mathrm{N}=192)\end{array}$ & $\begin{array}{l}\text { Without mela- } \\
\text { noma controls } \\
(\mathrm{N}=73)\end{array}$ \\
\hline Median age (years) & $60(27-93)$ & $71(55-86)$ \\
Gender (M/F) & $79 / 113$ & $28 / 45$ \\
$\begin{array}{l}\text { Medical history of pancreatic } \\
\text { cancer }\end{array}$ & 21 & 11 \\
$\begin{array}{l}\text { Multiple melanoma } \\
\text { Patients diagnosed with other } \\
\text { cancer }\end{array}$ & $77 / 192(40 \%)$ & - \\
\hline
\end{tabular}

Table 2 Sub-cohort characteristics of p16-Leiden carriers with/without pancreatic cancer

\begin{tabular}{lll}
\hline & $\begin{array}{l}\text { Pancreatic cancer cases } \\
(\mathrm{N}=50)\end{array}$ & $\begin{array}{l}\text { Non-Pancreatic } \\
\text { cancer controls } \\
(\mathrm{N}=143)\end{array}$ \\
\hline Median age (years) & $50(21-78)$ & $74(55-93)$ \\
Gender (M/F) & $17 / 33$ & $60 / 83$ \\
Medical history of melanoma & 21 & 81 \\
Multiple melanoma & $6 / 21(29 \%)$ & $37 / 81(46 \%)$ \\
Patients diagnosed with other cancer & 9 & 51 \\
\hline
\end{tabular}


Table 4 Association of rs36115365-C presence with PC and melanoma in p16-Leiden carriers

\begin{tabular}{lllllrl}
\hline Pancreatic cancer & \multicolumn{2}{l}{ MAF rs36115365 (G,C) } & Allelic OR & $95 \%$ CI & & p-value \\
\cline { 2 - 5 } & Cases & Controls & & & \\
\hline Pancreatic cancer & 0.23 & 0.23 & -0.027 & -0.804 & 0.750 & 0.946 \\
Melanoma & 0.21 & 0.29 & -0.703 & -1.201 & -0.205 & 0.006 \\
\hline
\end{tabular}

rs36115365-C [13], could explain modified risk in a homogeneous population of p16-Leiden carriers.

The MAF of rs36115365-C in the general European (Non-Finnish) population is 0.18 [18] and in the Netherlands specifically, it is 0.20 [19] indicating a common variant with high chances of detection. In this case, the second most-common allele $(\mathrm{C})$ was detected with MAFs ranging from 0.21 to 0.29 in 283 pl6-Leiden carriers, slightly higher than in the general population. A limitation of this study however is the small cohort size that could limit possibilities of detecting statistical associations. Moreover, selecting subjects older than 55 years of age not only reduced the control group size but also the possibility of developing PC or melanoma in the future was not fully excluded. A GEE statistical procedure was applied as it is appropriated for studying family based associations $[17,20]$. There was no significant association between rs $36115365-\mathrm{C}$ presence and $\mathrm{PC}$ risk in p16-Leiden carriers.

Several efforts in scientific literature focused on identifying genetic modifiers of PC risk in CDKN2A-mutation carriers. Yang et al., applied Whole Exome Sequencing (WES) in $66 \mathrm{PC}$ patients with/without a $C D K N 2 A$ mutation [21]. The combined data from five research groups, including 13 pancreatic CDKN2A mutated (p16-Leiden) cases from the Netherlands identified 35 variants in PC-related genes. Nominally significant associations were obtained for mismatch repair genes ( $M L H 1, M S H 2, M S H 6, P M S 2)$ in all PC patients, however, variants in $A T M, C P A 1$, and $P M S 2$ were only observed in $C D K N 2 A$ wild-type PC patients. Further, nine $C D K N 2 A$ mutated and four $C D K N 2 A$ wild-type $\mathrm{PC}$ patients had rare potentially deleterious variants in multiple PC-related genes. These results, therefore, suggest that a subset of PC patients may have increased risk because of germline mutations in multiple PC-related genes [21]. Nonetheless, p16-Leiden carriers described in the study by Yang were not included in the current study. In addition, the same group showed that sequencing analysis of $P A L B 2$, another high susceptibility gene for PC, did not reveal any deleterious mutations in PC patients from $C D K N 2 A$-mutated families [22]. Potjer et al. who studied the same cohort of p16-Leiden carriers as in the current study, did not identify an association of seven PC-associated SNPs with PC risk [12]. Therefore, consideration of other genetic modifiers yet unknown could be an additional explanation of the variability in occurrence of PC within p16-Leiden families. Moreover, epidemiological studies suggest that non-genetic factors may also contribute to
PC development specifically in p16-Leiden carriers, with the most significant one being smoking [23] as well as alcohol use and obesity in the general population [24]. Collectively these data suggest that rs36115365-C risk variant could not be used to estimate the risk of PC in p16-Leiden mutation carriers more accurately unlike in the European population published previously [13].

Modifier genes for melanoma have been well described in literature for $C D K N 2 A$ mutation carriers $[10,11,25,26]$. The variant rs36115365-C, previously published to be negatively correlated with melanoma risk [13] had a significantly negative association with melanoma development in this study. This effect did not remain however, when excluding probands from the analysis suggesting that ascertainment of melanoma cases influenced the results.

\section{Conclusion}

Here, no significant association was found between rs36115365-C presence and risk of PC development in p16-Leiden carriers in contrast to previous published literature in the European population. Reversely, a statistically significant protective effect was determined for melanoma risk in the same cohort of p16-Leiden carriers, an effect that lost significance when excluding melanoma probands. Collectively, genotyping and statistical data suggest that genetic modifiers for the prediction of PC and melanoma in p16-Leiden carriers remain to be determined.

Acknowledgements EC was funded from the European Union's Horizon 2020 research and innovation programme under Grant Agreement No. 641458. The work of MV, RvD, NvdS and NG was supported by a Grant of the Dutch Cancer Society (UL2012-5489) and TP was supported by the Dutch Cancer Society (\#UL 2015-7511).

Open Access This article is distributed under the terms of the Creative Commons Attribution 4.0 International License (http://creativeco mmons.org/licenses/by/4.0/), which permits unrestricted use, distribution, and reproduction in any medium, provided you give appropriate credit to the original author(s) and the source, provide a link to the Creative Commons license, and indicate if changes were made. 


\section{References}

1. Goldstein AM, Chan M, Harland M, Hayward NK, Demenais F, Bishop DT, Azizi E, Bergman W, Bianchi-Scarra G, Bruno W, Calista D, Albright LA, Chaudru V, Chompret A, Cuellar F, Elder DE, Ghiorzo P, Gillanders EM, Gruis NA, Hansson J, Hogg D, Holland EA, Kanetsky PA, Kefford RF, Landi MT, Lang J, Leachman SA, MacKie RM, Magnusson V, Mann GJ, Bishop JN, Palmer JM, Puig S, Puig-Butille JA, Stark M, Tsao H, Tucker MA, Whitaker L, Yakobson E (2007) Features associated with germline CDKN2A mutations: a GenoMEL study of melanoma-prone families from three continents. J Med Genet 44(2):99-106.https://doi.org/10.1136/jmg.2006.043802

2. Gruis NA, van der Velden PA, Sandkuijl LA, Prins DE, WeaverFeldhaus J, Kamb A, Bergman W, Frants RR (1995) Homozygotes for CDKN2 (p16) germline mutation in Dutch familial melanoma kindreds. Nat Genet 10:351. https://doi.org/10.1038/ ng0795-351

3. Bishop DT, Demenais F, Goldstein AM, Bergman W, Bishop JN, Bressac-de Paillerets B, Chompret A, Ghiorzo P, Gruis N, Hansson J, Harland M, Hayward N, Holland EA, Mann GJ, Mantelli M, Nancarrow D, Platz A, Tucker MA (2002) Geographical variation in the penetrance of CDKN2A mutations for melanoma. J Nat1 Cancer Inst 94(12):894-903

4. Vasen HF, Gruis NA, Frants RR, van Der Velden PA, Hille ET, Bergman W (2000) Risk of developing pancreatic cancer in families with familial atypical multiple mole melanoma associated with a specific 19 deletion of p16 (p16-Leiden). Int J Cancer 87(6):809-811

5. de Snoo FA, Bishop DT, Bergman W, van Leeuwen I, van der Drift C, van Nieuwpoort FA, Out-Luiting CJ, Vasen HF, ter Huurne JA, Frants RR, Willemze R, Breuning MH, Gruis NA (2008) Increased risk of cancer other than melanoma in CDKN2A founder mutation (p16-Leiden)-positive melanoma families. Clin Cancer Res 14(21):7151-7157. https://doi.org/10.1158/10780432.ccr-08-0403

6. Vasen H, Ibrahim I, Ponce CG, Slater EP, Matthai E, Carrato A, Earl J, Robbers K, van Mil AM, Potjer T, Bonsing BA, de Vos Tot Nederveen Cappel WH, Bergman W, Wasser M, Morreau H, Kloppel G, Schicker C, Steinkamp M, Figiel J, Esposito I, Mocci E, Vazquez-Sequeiros E, Sanjuanbenito A, Munoz-Beltran M, Montans J, Langer P, Fendrich V, Bartsch DK (2016) Benefit of surveillance for pancreatic cancer in high-risk individuals: outcome of long-term prospective follow-up studies from three European Expert Centers. J Clin Oncol 34(17):2010-2019. https ://doi.org/10.1200/jco.2015.64.0730

7. Ilic M, Ilic I (2016) Epidemiology of pancreatic cancer. World J Gastroenterol 22(44):9694-9705. https://doi.org/10.3748/wjg. v22.i44.9694

8. Siegel RL, Miller KD, Jemal A (2016) Cancer statistics, 2016. CA: A Cancer J Clin 66 (1):7-30. https://doi.org/10.3322/caac.21332

9. Shin EJ, Canto MI (2012) Pancreatic cancer screening. Gastroenterol Clin N Am 41(1):143-157. https://doi.org/10.1016/j. gtc.2011.12.001

10. van der Velden PA, Sandkuijl LA, Bergman W, Pavel S, van Mourik L, Frants RR, Gruis NA (2001) Melanocortin-1 receptor variant R151C modifies melanoma risk in Dutch families with melanoma. Am J Hum Genet 69(4):774-779

11. Demenais F, Mohamdi H, Chaudru V, Goldstein AM, Newton Bishop JA, Bishop DT, Kanetsky PA, Hayward NK, Gillanders E, Elder DE, Avril MF, Azizi E, van Belle P, Bergman W, BianchiScarra G, Bressac-de Paillerets B, Calista D, Carrera C, Hansson J, Harland M, Hogg D, Hoiom V, Holland EA, Ingvar C, Landi MT, Lang JM, Mackie RM, Mann GJ, Ming ME, Njauw CJ, Olsson H, Palmer J, Pastorino L, Puig S, Randerson-Moor J, Stark
M, Tsao H, Tucker MA, van der Velden P, Yang XR, Gruis N (2010) Association of MC1R variants and host phenotypes with melanoma risk in CDKN2A mutation carriers: a GenoMEL study. J Natl Cancer Inst 102(20):1568-1583. https://doi.org/10.1093/ jnci/djq363

12. Potjer TP, van der Stoep N, Houwing-Duistermaat JJ, Konings IC, Aalfs CM, van den Akker PC, Ausems MG, Dommering CJ, van der Kolk LE, Maiburg MC, Spruijt L, Wagner A, Vasen HF, Hes FJ (2015) Pancreatic cancer-associated gene polymorphisms in a nation-wide cohort of p16-Leiden germline mutation carriers; a case-control study. BMC Res Notes 8:264. https://doi. org/10.1186/s13104-015-1235-4

13. Fang J, Jia J, Makowski M, Xu M, Wang Z, Zhang T, Hoskins JW, Choi J, Han Y, Zhang M, Thomas J, Kovacs M, Collins I, Dzyadyk M, Thompson A, O’Neill M, Das S, Lan Q, Koster R, Stolzenberg-Solomon RS, Kraft P, Wolpin BM, Jansen P, Olson S, McGlynn KA, Kanetsky PA, Chatterjee N, Barrett JH, Dunning AM, Taylor JC, Newton-Bishop JA, Bishop DT, Andresson T, Petersen GM, Amos CI, Iles MM, Nathanson KL, Landi MT, Vermeulen M, Brown KM, Amundadottir LT (2017) Functional characterization of a multi-cancer risk locus on chr5p15.33 reveals regulation of TERT by ZNF148. Nat Commun 8:15034. https:// doi.org/10.1038/ncomms15034

14. Rachakonda S, Kong H, Srinivas N, Garcia-Casado Z, Requena C, Fallah M, Heidenreich B, Planelles D, Traves V, Schadendorf D, Nagore E, Kumar R (2018) Telomere length, telomerase reverse transcriptase promoter mutations, and melanoma risk. Genes Chromosomes Cancer. https://doi.org/10.1002/gcc.22669

15. Fortes C, Mastroeni S, Melchi F, Anzidei P, Innocenzi L, Giovinazzo R, Antonelli G, Pasquini P, Venanzetti F (2010) P5 Polymorphisms in GSTM1, GSTT1, coffee consumption and cutaneous melanoma risk. Melanoma Res 20:e45-e46. https://doi. org/10.1097/01.cmr.0000382837.61146.76

16. Randerson-Moor JA, Taylor JC, Elliott F, Chang YM, Beswick S, Kukalizch K, Affleck P, Leake S, Haynes S, Karpavicius B, Marsden J, Gerry E, Bale L, Bertram C, Field H, Barth JH, Silva Idos S, Swerdlow A, Kanetsky PA, Barrett JH, Bishop DT, Bishop JA (2009) Vitamin D receptor gene polymorphisms, serum 25-hydroxyvitamin D levels, and melanoma: UK case-control comparisons and a meta-analysis of published VDR data. Eur J Cancer (Oxford, England: 1990) 45(18):3271-3281. https://doi. org/10.1016/j.ejca.2009.06.011

17. Liang K-Y, Zeger SL (1986) Longitudinal data analysis using generalized linear models. Biometrika 73(1):13-22. https://doi. org/10.1093/biomet/73.1.13

18. Lek M, Karczewski KJ, Minikel EV, Samocha KE, Banks E, Fennell T, O'Donnell-Luria AH, Ware JS, Hill AJ, Cummings BB, Tukiainen T, Birnbaum DP, Kosmicki JA, Duncan LE, Estrada K, Zhao F, Zou J, Pierce-Hoffman E, Berghout J, Cooper DN, Deflaux N, DePristo M, Do R, Flannick J, Fromer M, Gauthier L, Goldstein J, Gupta N, Howrigan D, Kiezun A, Kurki MI, Moonshine AL, Natarajan P, Orozco L, Peloso GM, Poplin R, Rivas MA, Ruano-Rubio V, Rose SA, Ruderfer DM, Shakir K, Stenson PD, Stevens C, Thomas BP, Tiao G, Tusie-Luna MT, Weisburd B, Won H-H, Yu D, Altshuler DM, Ardissino D, Boehnke M, Danesh J, Donnelly S, Elosua R, Florez JC, Gabriel SB, Getz G, Glatt SJ, Hultman CM, Kathiresan S, Laakso M, McCarroll S, McCarthy MI, McGovern D, McPherson R, Neale BM, Palotie A, Purcell SM, Saleheen D, Scharf JM, Sklar P, Sullivan PF, Tuomilehto J, Tsuang MT, Watkins HC, Wilson JG, Daly MJ, MacArthur DG, Exome Aggregation C (2016) Analysis of protein-coding genetic variation in 60,706 humans. Nature 536:285. https://doi. org/10.1038/nature19057

19. Boomsma DI, Wijmenga C, Slagboom EP, Swertz MA, Karssen LC, Abdellaoui A, Ye K, Guryev V, Vermaat M, van Dijk F, Francioli LC, Hottenga JJ, Laros JF, Li Q, Li Y, Cao H, Chen R, 
Du Y, Li N, Cao S, van Setten J, Menelaou A, Pulit SL, HehirKwa JY, Beekman M, Elbers CC, Byelas H, de Craen AJ, Deelen P, Dijkstra M, den Dunnen JT, de Knijff P, Houwing-Duistermaat J, Koval V, Estrada K, Hofman A, Kanterakis A, Enckevort D, Mai H, Kattenberg M, van Leeuwen EM, Neerincx PB, Oostra B, Rivadeneira F, Suchiman EH, Uitterlinden AG, Willemsen G, Wolffenbuttel BH, Wang J, de Bakker PI, van Ommen GJ, van Duijn CM (2014) The genome of the Netherlands: design, and project goals. Eur J Hum Genet (EJHG) 22(2):221-227. https:// doi.org/10.1038/ejhg.2013.118

20. Septier M, Peyre H, Amsellem F, Beggiato A, Maruani A, Poumeyreau M, Amestoy A, Scheid I, Gaman A, Bolognani F, Honey G, Bouquet C, Ly-Le Moal M, Bouvard M, Leboyer M, Bourgeron $\mathrm{T}$, Delorme R (2018) Increased risk of ADHD in families with ASD. Eur Child Adolesc Psychiatry. https://doi.org/10.1007/ s00787-018-1206-0

21. Yang XR, Rotunno M, Xiao Y, Ingvar C, Helgadottir H, Pastorino L, van Doorn R, Bennett H, Graham C, Sampson JN, Malasky M, Vogt A, Zhu B, Bianchi-Scarra G, Bruno W, Queirolo P, Fornarini G, Hansson J, Tuominen R, Burdett L, Hicks B, Hutchinson A, Jones K, Yeager M, Chanock SJ, Landi MT, Höiom V, Olsson H, Gruis N, Ghiorzo P, Tucker MA, Goldstein AM (2016) Multiple rare variants in high-risk pancreatic cancer-related genes may increase risk for pancreatic cancer in a subset of patients with and without germline CDKN2A mutations. Hum Genet 135(11):1241-1249. https://doi.org/10.1007/s00439-016-1715-1

22. Yang XR, Jessop L, Myers T, Amundadottir L, Pfeiffer RM, Wheeler W, Pike KM, Yuenger J, Burdett L, Yeager M, Chanock SJ, Tucker MA, Goldstein AM (2011) Lack of germline PALB2 mutations in melanoma-prone families with CDKN2A mutations and pancreatic cancer. Fam Cancer 10(3):545-548. https://doi. org/10.1007/s10689-011-9447-9

23. Potjer TP, Kranenburg HE, Bergman W, van Monsjou HS, BargeSchaapveld DQ, Vasen HF (2015) de Vos tot Nederveen Cappel WH. Prospective risk of cancer and the influence of tobacco use in carriers of the p16-Leiden germline variant. Eur J Hum Genet (EJHG) 23(5):711-714. https://doi.org/10.1038/ejhg.2014.187

24. Klein AP, Lindstrom S, Mendelsohn JB, Steplowski E, Arslan AA, Bueno-de-Mesquita HB, Fuchs CS, Gallinger S, Gross M, Helzlsouer K, Holly EA, Jacobs EJ, Lacroix A, Li D, Mandelson MT, Olson SH, Petersen GM, Risch HA, Stolzenberg-Solomon RZ, Zheng W, Amundadottir L, Albanes D, Allen NE, Bamlet WR, Boutron-Ruault MC, Buring JE, Bracci PM, Canzian F, Clipp S, Cotterchio M, Duell EJ, Elena J, Gaziano JM, Giovannucci EL, Goggins M, Hallmans G, Hassan M, Hutchinson A, Hunter DJ, Kooperberg C, Kurtz RC, Liu S, Overvad K, Palli D, Patel AV, Rabe KG, Shu XO, Slimani N, Tobias GS, Trichopoulos D, Van Den Eeden SK, Vineis P, Virtamo J, Wactawski-Wende J, Wolpin BM, Yu H, Yu K, Zeleniuch-Jacquotte A, Chanock SJ, Hoover RN, Hartge P, Kraft P (2013) An absolute risk model to identify individuals at elevated risk for pancreatic cancer in the general population. PLoS ONE 8(9):e72311. https://doi.org/10.1371/journ al.pone.0072311

25. Yang XR, Pfeiffer RM, Wheeler W, Yeager M, Chanock S, Tucker MA, Goldstein AM (2009) Identification of modifier genes for cutaneous malignant melanoma in melanoma-prone families with and without CDKN2A mutations. Int J Cancer 125(12):29122917. doi:https://doi.org/10.1002/ijc.24622

26. Liang XS, Pfeiffer RM, Wheeler W, Maeder D, Burdette L, Yeager M, Chanock S, Tucker MA, Goldstein AM, Yang XR (2012) Genetic variants in DNA repair genes and the risk of cutaneous malignant melanoma in melanoma-prone families with/without CDKN2A mutations. Int J Cancer 130(9):2062-2066. doi:https ://doi.org/10.1002/ijc.26231

Publisher's Note Springer Nature remains neutral with regard to jurisdictional claims in published maps and institutional affiliations. 